\title{
Article \\ Sustainability Levels in Comparison with Mechanical Properties and Durability of Pumice High-Performance Concrete
}

\author{
Kristýna Hrabová ${ }^{1}$, Petr Lehner ${ }^{2, *}$, Pratanu Ghosh ${ }^{3}$, Petr Konečný ${ }^{2}\left(\mathbb{D}\right.$ and Břetislav Teplý ${ }^{1}(\mathbb{C}$ \\ 1 Faculty of Civil Engineering, Brno University of Technology, Veveří 331/95, 60200 Brno, Czech Republic; \\ kristyna.hrabova@vutbr.cz (K.H.); teply.b@fce.vutbr.cz (B.T.) \\ 2 Faculty of Civil Engineering, VŠB-Technical University of Ostrava, L. Podéště 1875, \\ 70800 Ostrava-Poruba, Czech Republic; petr.konecny@vsb.cz \\ 3 Department of Civil and Environmental Engineering, California State University Fullerton, \\ Fullerton, CA 92831, USA; pghosh@fullerton.edu \\ * Correspondence: petr.lehner@vsb.cz
}

\section{check for}

updates

Citation: Hrabová, K.; Lehner, P. Ghosh, P.; Konečný, P.; Teplý, B. Sustainability Levels in Comparison with Mechanical Properties and Durability of Pumice

High-Performance Concrete. Appl.

Sci. 2021, 11, 4964. https://

doi.org/10.3390/app11114964

Academic Editors: Chiara Giosuè,

Maria Letizia Ruello and

Alessandra Mobili

Received: 14 May 2021

Accepted: 27 May 2021

Published: 28 May 2021

Publisher's Note: MDPI stays neutral with regard to jurisdictional claims in published maps and institutional affiliations.

Copyright: (c) 2021 by the authors. Licensee MDPI, Basel, Switzerland. This article is an open access article distributed under the terms and conditions of the Creative Commons Attribution (CC BY) license (https:// creativecommons.org/licenses/by/ $4.0 /)$.

\begin{abstract}
In the production of cement and concrete, mechanical and durable properties are essential, along with reasonable cost and sustainability. This study aimed to apply an evaluation procedure of the level of sustainability of mixtures of high-performance concretes (HPC) with various ecofriendly supplementary cementitious materials (SCM). The major supplementary cementitious materials (SCMs), namely, volcanic pumice pozzolan (VPP), Class $\mathrm{C}$ and $\mathrm{F}$ fly ash, ground granulated blast furnace slag of grade 120, silica fume, and metakaolin, were included. Twenty-seven concrete mixtures were analyzed using a previously presented comprehensive material sustainability indicator in a cost-effective variant. The results indicated that the rank of the concretes differed at 28,56 , and 91 days after concreting. In addition, the study showed no correlation of strength and diffusion parameters with sustainability indicators. Finally, this study will contribute to the optimal selection of mixtures of HPC with VPP in terms of sustainability, cost, and durability for future implementation in reinforced concrete bridge deck slabs and pavements. The values of sustainability indicators for pumice-based mixtures were compared with those for other SCMs, highlighting the sustainable performance of volcanic ash-based SCM.
\end{abstract}

Keywords: sustainability; concrete; SCM; pozzolanic; eco-costs; durability; life cycle assessment

\section{Introduction}

In general, concrete is the most popular building construction material in the world due to its cost, technical properties, and durability characteristics. The impacts of the selected materials-e.g., steel or reinforced concrete in both civil and transportation infrastructure constructions-on the economic and ecological levels are often compared. In the transportation infrastructure, concrete is more valuable as it allows the creation of structures of various shapes and is used in all parts of a construction. In addition to steel reinforcement in reinforced concrete [1], cement is the most important component in this respect-historically, ordinary Portland cement (OPC) is the most widely used [2].

It should be noted that there are ways to reduce the cost of concrete production while maintaining its desirable properties, for example, by replacing the aggregates [3-6], but this is not the subject of the present research. Concrete production alone emits almost $8 \%$ of global greenhouse gases [7-10], mainly due to the use of fossil fuels. A study shows that cement production and processing are responsible for $85 \%$ of $\mathrm{CO}_{2}$ production in the entire concrete industry [11].

A current and extremely large study involving thousands of scientific outputs has shown the modern trends of high-performance concretes (HPC), atypical reinforced concretes, their disadvantages and possibilities, and, above all, has provided a comprehensive overview of studies dealing with concrete with SCMs [12]. 
For this reason, it is highly desirable to seek alternative substitutes of OPC using various other SCMs [5-9]; therefore, research on the use of fly ash, slag, silica fume, and metakaolin has been gaining attention at a rapid pace in recent decades [13-17].

SCM replacement levels may vary from mixture to mixture based on chemical composition, cost, availability, and local resources. Most studies aim to present the strength properties or properties related to durability. Alternatively, researchers are looking for shortcomings in current testing methods due to different chemical compositions of concrete [18-20]. In many recent studies, a new SCM has been introduced, specifically, volcanic pumice pozzolan (VPP), which increases HPC performance in a significant manner [21-25].

For the needs of the presented investigation, the results from a previous study [26] were obtained and evaluated in terms of sustainability and other related factors. The acquisition of HPC material properties with SCM was a challenge in addition to the testing strategy. The evaluation of a high-quality mixture and especially the correct categorization of the results are important. Degradation of reinforced concrete structures is the result of the combined effects of environmental and mechanical damage, and owners pay significant attention to the issue of ageing [27-29].

The effect of degradation must be taken into account, with a strong emphasis on sustainability assessment [30,31].

This has a significant impact on performance requirements critical to the design procedure, life cycle analysis, reliability and, in addition, sustainability-based concepts [32-34].

The evaluation of the sustainability of concrete using the so-called sustainability indicators, including material properties, durability, and eco-cost, was presented earlier in $[28,34,35]$, using an indicator marked as $k_{S B}$ (see Equation (1) in Section 2.4). The methodology was improved and enriched later by others authors [36], who included financial costs for the material and the production of concrete, thus creating the indicator $k_{\mathrm{SB}, \mathrm{C}}$.

Moreover, a holistic indicator framework for concrete material sustainability evaluation was presented in another study [37].

It is also worth mentioning that the issue of sustainability is currently more emphasized in the regulations-e.g., for the current ACI 318 Code cycle [38], a new subcommittee was established to work on greatly expanding the concrete building code provisions related to sustainability design. A similar situation applies to the forthcoming fibMC2020 [39].

These above-mentioned sustainability indicators can serve as a yardstick for selecting the most appropriate mixture for a broader study and preparing its future implementation, and this is the procedure presented in this article. Material properties are adopted from the study [26]. The diffusion coefficient was included as an indicator of durability, as well as the cost and eco-cost of concrete mixtures for evaluated their rank at three different concrete ages $(28,56$, and 91 days). The correlation between the properties directly measured (strength, diffusion parameter) and those derived (sustainability indicators) was also evaluated. We examined the hypothesis that it is not sufficient to evaluate only the strength of concrete or only the durability characteristics, but on the contrary, the sustainability indicator may show a significantly different rank of the investigated concrete mixtures. The results of sustainability indicators of pumice-based HPC mixtures were compared with results for other SCMs [36], highlighting the sustainable performance of volcanic ashes.

\section{Materials and Methods}

The composition of the investigated concrete mixtures, the results obtained from the adopted study, and the values obtained from the cost and eco-cost evaluation are presented below. A basic description of the method used, the so-called sustainability indicators, and its applicability are also illustrated.

\subsection{Volcanic Pumice Pozzolan}

VPP is a natural material of volcanic origin and is abundant on the west coast of the United States. As of 2017, California state lawmakers have mandated state-funded projects to report global warming potential (GWP) information based on the use of materials in 
the project to be assigned an upper limit. As there is still no clear methodology to reduce $\mathrm{CO}_{2}$ emissions in concrete, detailed research is in demand in this area [40]. This SCM is also extensively used in other parts of the world. As an example, VPP is widely used as a supplement to Portland cement in countries including Italy, Germany, Kenya, Turkey, China, and Greece [41] and is a good example of a sustainable substitute for concrete mineral admixtures.

Basic data such as strength, diffusion coefficients, and material composition were obtained from an extensive durability study of volcanic pumice-based ultrafine HPC mixtures [25]. As an example of the developed methodology, 27 different concrete mixtures were investigated, including the reference mixture of ordinary Portland cement (OPC), binary mixtures (OPC and one SCM), and ternary mixtures (OPC and two SCMs) integrating VPP [25]. The chemical properties of OPC, VPP, and other SCMs are shown in Table 1 [26].

Table 1. Chemical composition of cementitious materials [26].

\begin{tabular}{|c|c|c|c|c|c|c|c|}
\hline Chemical [\%] & Cement Type II/V & Class C Fly Ash & Class F Fly Ash & Slag G120 & Silica Fume & Metakaolin & Pumice \\
\hline $\mathrm{SiO}_{2}$ & 21.20 & 34.02 & 45.05 & 36.81 & 97.90 & 51.95 & 87.40 \\
\hline $\mathrm{Al}_{2} \mathrm{O}_{3}$ & 3.90 & 18.20 & 23.71 & 9.66 & 0.18 & 44.27 & 10.52 \\
\hline $\mathrm{Fe}_{2} \mathrm{O}_{3}$ & 3.50 & 6.59 & 16.43 & 0.61 & 0.07 & 0.41 & 0.174 \\
\hline $\mathrm{MgO}$ & 2.10 & 5.06 & 0.88 & 10.03 & 0.21 & 0.05 & 0.126 \\
\hline $\mathrm{CaO}$ & 2.70 & 2.70 & 0.68 & - & 0.17 & 0.02 & - \\
\hline $\mathrm{Na}_{2} \mathrm{O}+\mathrm{K}_{2} \mathrm{O}$ & 63.10 & 27.18 & 3.78 & 36.77 & 0.42 & 0.06 & - \\
\hline $\mathrm{MnO}$ & 0.54 & 1.91 & 2.26 & 0.66 & 0.71 & 0.30 & - \\
\hline $\mathrm{ZnO}$ & - & - & - & - & 0.03 & - & - \\
\hline $\mathrm{SiO}_{2}$ & - & - & - & - & 0.08 & - & - \\
\hline $\mathrm{SrO}^{-}$ & - & - & - & 1.10 & - & - & - \\
\hline $\mathrm{Cl}$ & - & - & - & 0.05 & - & - & - \\
\hline $\mathrm{Fe}_{2} \mathrm{O}_{4}$ & - & - & - & - & 0.09 & - & 0.194 \\
\hline $\mathrm{Na}$ & - & - & - & - & - & - & 0.128 \\
\hline K & - & - & - & - & - & - & 0.099 \\
\hline $\mathrm{Ca}$ & - & - & - & - & - & - & 0.090 \\
\hline $\mathrm{TiO}_{2}$ & - & - & - & - & - & - & 0.0074 \\
\hline $\mathrm{SO}_{4}$ & - & - & - & - & - & - & 0.0041 \\
\hline $\mathrm{H}_{2} \mathrm{O}$ & & & & & & & 1.110 \\
\hline
\end{tabular}

\subsection{Investigated Mixture Composition}

Concrete mixtures were designed with a water/cementitious materials ratio of 0.4 and contained $335 \mathrm{~kg} / \mathrm{m}^{3}$ of cementitious materials, $147 \mathrm{~kg} / \mathrm{m}^{3}$ of water, $1038 \mathrm{~kg} / \mathrm{m}^{3}$ of gravel, and between $701 \mathrm{~kg} / \mathrm{m}^{3}$ to $731 \mathrm{~kg} / \mathrm{m}^{3}$ of natural sand. The basic element was the Portland Cement Type II-V (TII-V), which is widely used in California due to the sulphate attack problem. It is to be noted that Type I cement is prohibited in California. Various SCMs were utilized, namely, Class C fly ash (C), Class F fly Ash (F), Silica fume (SF), ground granulated blast furnace slag of grade 120 (G120S), Metakaolin (M), and Volcanic Pumice Pozzolan (P). Volcanic pumice was the major ingredient, as it is incorporated in all binary and ternary concrete mixtures. The specific gravity of Cement TII/V is 3.15, that of Class C Fly Ash is 2.32, that of Class F Fly Ash is 2.32, that of GGBFS 120 is 2.92, that of Silica Fume is 2.22, that of Metakaolin is 2.6, that of Pumice is 2.35, that of Natural Sand is 2.66, and that of Gravel is 2.71 .

Furthermore, a water-reducing admixture (Glenium 7500) and an air-entraining admixture (MBVR AE90) were used to achieve better processability and other workability specifications. Mixtures were marked according to the cementitious materials and their percentage replacement by mass, e.g., 70TII-V / 15F/15P stands for 70\% Type II-V Cement, $15 \%$ Class F fly ash, and 15\% Pumice (see Figure 1). It can be noticed that the first concrete mixture was taken as a reference for all calculations, and was designated as OPC. 


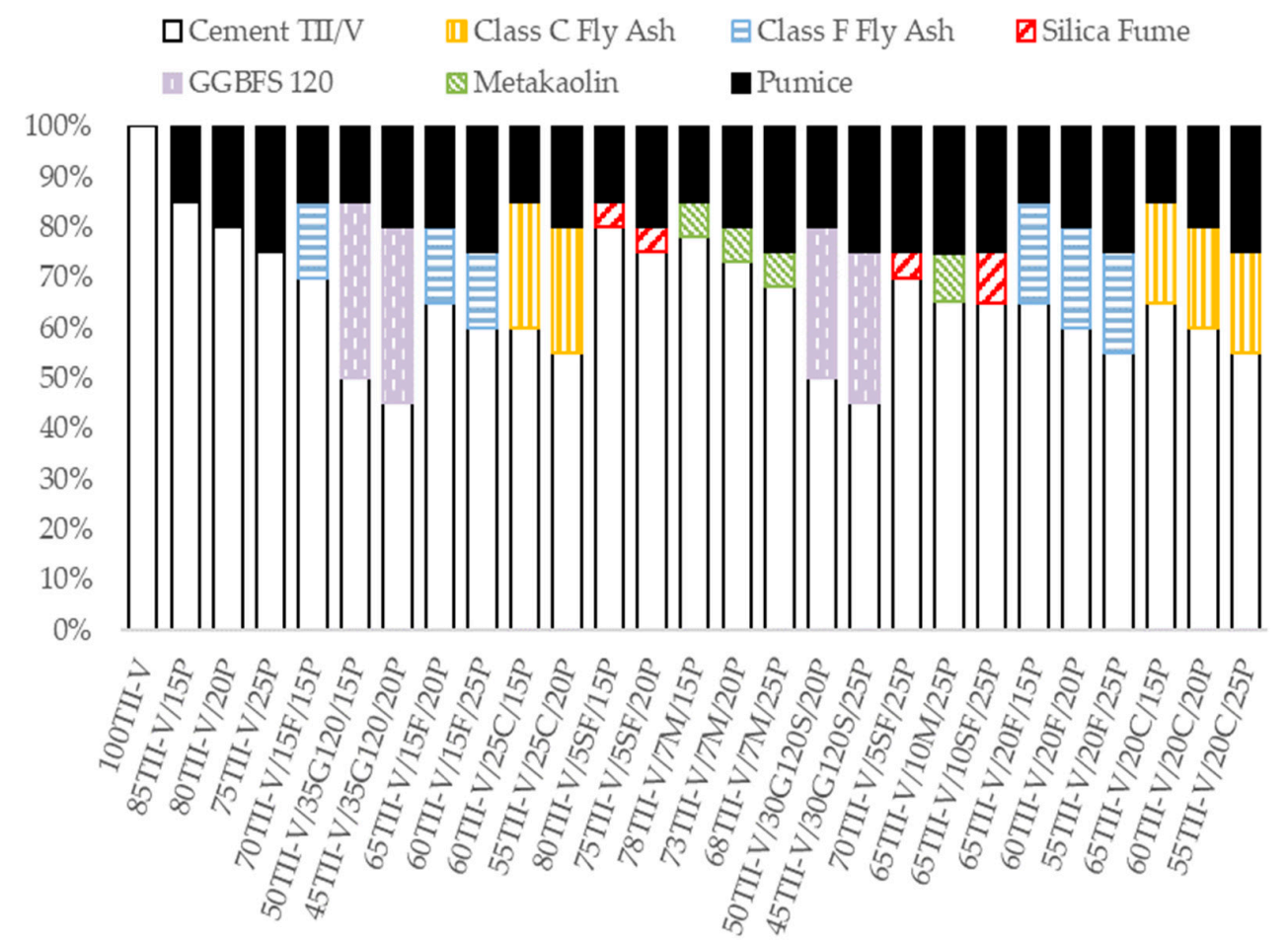

Figure 1. Composition of the cementitious materials of concrete mixtures.

\subsection{Material Properties}

A published article studied the strengths and electrochemical properties at 28, 56 and 91 days after concreting [26]. For further sustainability assessment, the strength values were converted from psi to MPa. Furthermore, diffusion parameters were subsequently computed from the measured values of the charge passed according to the ASTM C1202 standard (a detailed description of the measurement is provided in [42,43]). Diffusion coefficients $\left(D_{c}\right)$ were also obtained at 28,56 , and 91 days after concreting, using the NernstEinstein equation [44]. The environmental costs and the cost of each component of the concrete mixture were obtained from a database [45,46] and computed for each concrete mixture. It should be noted that these costs are related to the area of origin, i.e., the USA. Table 2 shows the values for all concrete mixtures.

\subsection{Sustainability Indicator}

Sustainability can be evaluated using the sustainability indicator $k_{\mathrm{SB}}$, which has already been described in details, and the cost of the concrete mixture has been considered (material and production) to obtain a modified indicator, i.e., $k_{\mathrm{SB}, \mathrm{C}}[34,36,47]$. The methodology used was based on previous published findings [35]. It should be noted that the cost of the material is mostly dependent on the region or country. The present analysis focused on the values for the USA. As the design of the concrete structure ensures structural safety and serviceability, along with durability, robustness, sustainability, and resilience, the sustainability indicator $k_{\mathrm{SB}, \mathrm{C}}$ can be incorporated to create a rank of concrete mixtures. The main advantage of $k_{\mathrm{SB}, \mathrm{C}}$ is its complexity, which includes all aspects, namely, strength, resilience, ecology, and economy. Equation (1) [34] was used for the computation of $k_{\mathrm{SB}}$ :

$$
k_{\mathrm{SB}}=\frac{\frac{R}{L_{\mathrm{ref}}} \times \frac{L}{L_{\mathrm{ref}}}}{\frac{E}{E_{\mathrm{ref}}}}
$$

where:

- $\quad R$ is the performance-suitable for the mechanical characteristics of concrete, namely, compressive strength [MPa] 
- $\quad L$ is the service life-using a suitable analytical model (see e.g., [6,7]), the service life of $L$ [years] is then determined. Instead of the model, alternatively, a quantity characterizing the service life related to a certain degradation phenomenon can be used for $L$-in the present case, it is a diffusion parameter used to calculate the resistance of concrete to chloride ions and in connection with corrosion of reinforcement $[9,10]$

- $\quad E$ is the eco-cost, i.e., the amount that could be spent to reduce the environmental impact to a sustainable level. It includes the impact of mining and processing of materials

- $\quad R_{\text {ref, }} L_{\text {ref }}$, and $E_{\text {ref }}$ are optional values, in this case, relevant to the reference concrete mixture (OPC).

The extension of the sustainability indicator by the cost of the material can be considered in Equation (2) [36] to obtain $k_{\mathrm{SB}, \mathrm{C}}$ :

$$
k_{\mathrm{SB}}=\frac{\frac{R}{L_{\mathrm{ref}}} \times \frac{L}{L_{\mathrm{ref}}}}{\frac{E}{E_{\mathrm{ref}}} \times \frac{C}{C_{\mathrm{ref}}}}
$$

The description of the parameters is listed below:

- $\quad C$ is the cost, i.e., the price of all materials according to the specific composition of concrete, depending mainly on the region or country

- $\quad C_{\text {ref }}$ is a cost related to the reference concrete.

Considering these parameters, it is possible to categorize concrete mixtures based on data obtained from previous research studies. The highest values of $k_{\mathrm{SB}}$ and $k_{\mathrm{SB}, \mathrm{C}}$ show the most advantageous concrete mixture in the studied group in terms of sustainability. Details of the entire methodology for evaluating the sustainability indicator are described comprehensively in a published study [36].

Table 2. Diffusion coefficient $D_{\mathrm{c}}$, compressive strength, eco-cost, and cost for all concrete mixtures.

\begin{tabular}{|c|c|c|c|c|c|c|c|c|}
\hline Mix ID & $\begin{array}{c}D_{\mathrm{c}} \\
(28 \text { Days) } \\
\times 10^{-12} \\
{\left[\mathrm{~m}^{2} / \mathrm{s}\right]}\end{array}$ & $\begin{array}{c}D_{\mathrm{c}} \\
\text { (56 Days) } \\
\times 10^{-12} \\
{\left[\mathrm{~m}^{2} / \mathrm{s}\right]}\end{array}$ & $\begin{array}{c}D_{\mathrm{c}} \\
(91 \text { Days) } \\
\times 10^{-12} \\
{\left[\mathrm{~m}^{2} / \mathrm{s}\right]}\end{array}$ & $\begin{array}{c}\text { Strength } \\
\text { (28 Days) } \\
\text { [MPa] }\end{array}$ & $\begin{array}{c}\text { Strength } \\
\text { (56 Days) } \\
\text { [MPa] }\end{array}$ & $\begin{array}{c}\text { Strength } \\
\text { (91 Days) } \\
\text { [MPa] }\end{array}$ & $\begin{array}{c}\text { Eco-Costs } \\
{\left[€ / \mathrm{m}^{3}\right]}\end{array}$ & $\begin{array}{l}\text { Costs } \\
{\left[€ / \mathrm{m}^{3}\right]}\end{array}$ \\
\hline 100TII-V & 6.14 & 5.33 & 4.05 & 27.08 & 34.70 & 36.76 & 51.66 & 60.59 \\
\hline $85 \mathrm{TII}-\mathrm{V} / 15 \mathrm{P}$ & 4.90 & 2.49 & 1.60 & 39.58 & 49.81 & 54.92 & 45.82 & 57.91 \\
\hline $80 \mathrm{TII}-\mathrm{V} / 20 \mathrm{P}$ & 5.44 & 2.57 & 1.58 & 34.96 & 45.45 & 50.02 & 43.85 & 57.19 \\
\hline 75TII-V / 25P & 3.85 & 2.15 & 1.33 & 35.44 & 40.89 & 46.05 & 41.89 & 55.97 \\
\hline 70TII-V/15F/15P & 4.32 & 2.45 & 1.56 & 31.60 & 32.54 & 41.16 & 43.44 & 55.57 \\
\hline 50TII-V /35G120/15P & 2.06 & 1.33 & 0.92 & 37.43 & 41.45 & 45.82 & 40.37 & 57.65 \\
\hline 45TII-V/35G120/20P & 2.77 & 1.71 & 1.08 & 34.92 & 39.81 & 42.89 & 38.4 & 57.42 \\
\hline 65TII-V /15F/20P & 3.72 & 1.71 & 1.04 & 39.35 & 47.27 & 53.28 & 41.47 & 55.33 \\
\hline $60 \mathrm{TII}-\mathrm{V} / 15 \mathrm{~F} / 25 \mathrm{P}$ & 3.39 & 1.92 & 0.98 & 28.26 & 34.63 & 41.00 & 39.51 & 54.44 \\
\hline 60TII-V /25C /15P & 5.17 & 2.64 & 1.62 & 37.81 & 44.66 & 50.67 & 41.01 & 54.77 \\
\hline $55 \mathrm{TII}-\mathrm{V} / 25 \mathrm{C} / 20 \mathrm{P}$ & 3.20 & 1.78 & 0.99 & 35.16 & 46.53 & 54.44 & 39.05 & 53.55 \\
\hline $80 \mathrm{TII}-\mathrm{V} / 5 \mathrm{SF} / 15 \mathrm{P}$ & 2.76 & 1.30 & 0.95 & 32.31 & 41.18 & 49.21 & 43.91 & 64.81 \\
\hline 75TII-V/5SF /20P & 2.89 & 1.31 & 0.91 & 32.39 & 44.80 & 49.37 & 41.95 & 64.25 \\
\hline 78TII-V/7M/15P & 1.77 & 1.18 & 0.87 & 48.65 & 55.10 & 50.55 & 43.91 & 56.26 \\
\hline 73TII-V/7M/20P & 1.77 & 1.16 & 0.80 & 48.72 & 54.63 & 55.34 & 41.94 & 55.7 \\
\hline $68 \mathrm{TII}-\mathrm{V} / 7 \mathrm{M} / 25 \mathrm{P}$ & 1.71 & 1.19 & 0.76 & 49.11 & 50.66 & 59.45 & 39.98 & 54.81 \\
\hline 50TII-V/30G120S/20P & 1.95 & 1.00 & 0.61 & 44.05 & 50.50 & 52.06 & 39.18 & 56.78 \\
\hline 45TII-V/30G120S/25P & 1.73 & 0.85 & 0.48 & 42.49 & 46.74 & 53.54 & 37.22 & 56.21 \\
\hline 70TII-V/5SF /25P & 1.69 & 0.79 & 0.44 & 45.65 & 53.75 & 57.19 & 39.99 & 63.03 \\
\hline $65 \mathrm{TII}-\mathrm{V} / 10 \mathrm{M} / 25 \mathrm{P}$ & 1.62 & 1.02 & 0.73 & 45.24 & 48.99 & 53.72 & 39.16 & 53.23 \\
\hline 65TII-V/10SF/25P & 1.20 & 0.56 & 0.38 & 41.15 & 53.04 & 52.60 & 38.08 & 69.76 \\
\hline $65 \mathrm{TII}-\mathrm{V} / 20 \mathrm{~F} / 15 \mathrm{P}$ & 1.49 & 0.78 & 0.53 & 31.11 & 36.78 & 41.60 & 42.64 & 54.84 \\
\hline $60 \mathrm{TII}-\mathrm{V} / 20 \mathrm{~F} / 20 \mathrm{P}$ & 1.28 & 0.69 & 0.48 & 32.00 & 38.34 & 39.77 & 40.68 & 53.95 \\
\hline $55 \mathrm{TII}-\mathrm{V} / 20 \mathrm{~F} / 25 \mathrm{P}$ & 1.01 & 0.49 & 0.33 & 32.02 & 41.37 & 40.91 & 38.72 & 53.39 \\
\hline $65 \mathrm{TII}-\mathrm{V} / 20 \mathrm{C} / 15 \mathrm{P}$ & 2.07 & 1.06 & 1.01 & 38.96 & 45.04 & 47.36 & 41.97 & 55.17 \\
\hline $60 \mathrm{TII}-\mathrm{V} / 20 \mathrm{C} / 20 \mathrm{P}$ & 2.52 & 1.23 & 0.81 & 46.06 & 48.26 & 54.79 & 40.01 & 54.28 \\
\hline $55 \mathrm{TII}-\mathrm{V} / 20 \mathrm{C} / 25 \mathrm{P}$ & 3.65 & 1.68 & 1.13 & 46.12 & 55.36 & 55.36 & 38.05 & 53.39 \\
\hline
\end{tabular}




\section{Results}

It was possible to evaluate the various groups of concrete mixtures and determine their rank in the group with the above-mentioned assumptions and the application of the methodology of sustainability indicators. The results represent the $k_{\mathrm{SB}}$ values and the respective rank, as well as the $k_{\mathrm{SB}, \mathrm{C}}$ values and the respective rank. Both parameters were calculated for three time periods. Subsequently, linear regression was applied in order to evaluate the correlation between $k_{\mathrm{SB}}$ and $k_{\mathrm{SB}, \mathrm{C}}$, which indicated how the cost determine fundamental differences of the material in the investigated group. Further evaluation was carried out considering $k_{\mathrm{SB}}$ correlation at different concrete ages, namely, 28 days versus 56 days, 28 days versus 91 days, and 56 days versus 91 days. Finally, our analysis showed a correlation of the strength and diffusion parameters with the $k_{\mathrm{SB}}$ and $k_{\mathrm{SB}, \mathrm{C}}$ indicators. It is worth mentioning that other possible regression curves did not show a higher agreement compared to linear regression. Therefore, only linear regression is presented herein. This allows understanding whether it is necessary to use indicators or whether it is possible to evaluate concrete in terms of sustainability purely based on material characteristics.

\subsection{Rank of Concrete Mixtures}

Equations (1) and (2) were used to obtain the rank of all mixtures. For example, the mixture $80 \mathrm{TII}-\mathrm{V} / 15 \mathrm{P}$ presented the following values after 28 days: $R=1.60 \mathrm{MPa}$ (strength), $L=4.90 \times 10^{-12} \mathrm{~m}^{2} / \mathrm{s}$ (diffusion coefficient), $E=54.91 € / \mathrm{m}^{3}$ and $C=44.57 € / \mathrm{m}^{3}$. The reference values of 100TII-V were selected for all mixtures after 28 days as $R_{\text {ref }}=6.16 \mathrm{MPa}$, $L_{\text {ref }}=27.08 \times 10^{-12} \mathrm{~m}^{2}, E_{\text {ref }}=50.95 € / \mathrm{m}^{3}$, and $C_{\text {ref }}=46.47 € / \mathrm{m}^{3}$. The result according to Equation (1) is 2.07 in 28 days, while, according to Equation (2), it is 2.16. All mixtures were calculated and then sorted from the highest to the lowest value - thus obtaining a rank. The results of the evaluation using the sustainability indicator at 28, 56, 91 days after concreting are shown in Figures $2-4$.

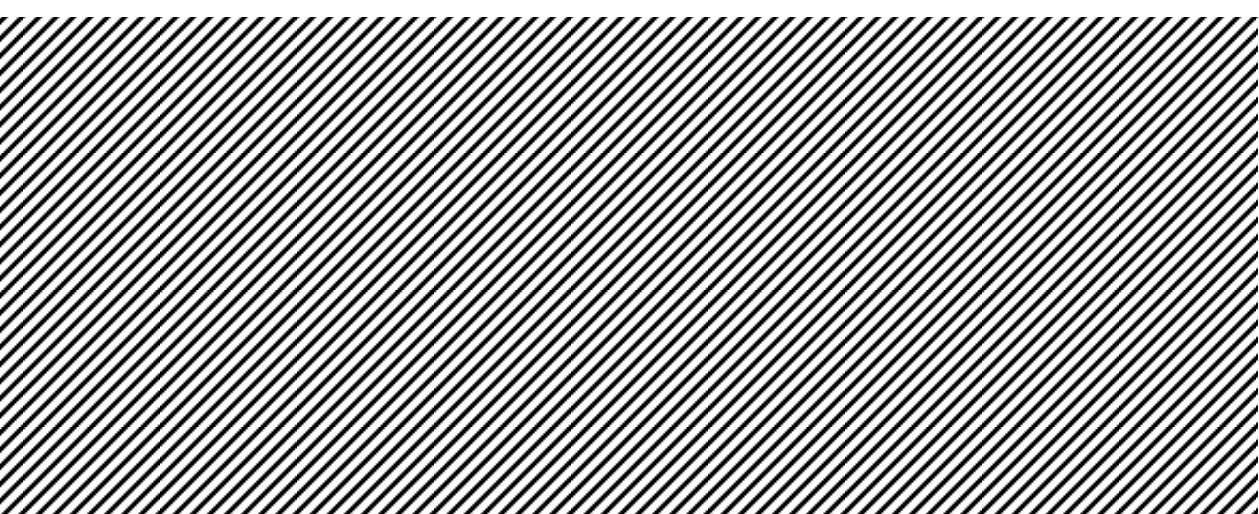

Figure 2. Sustainability indicators and rank of concrete mixtures 28 days after concreting (indicator value/rank).

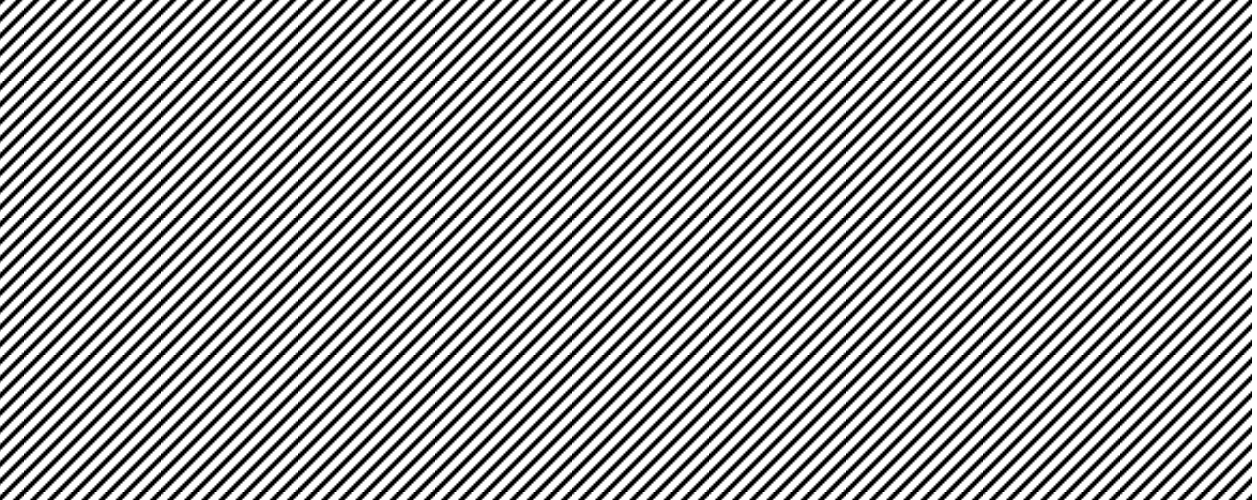

Figure 3. Sustainability indicators and rank of concrete mixtures 56 days after concreting (indicator value/rank). 
( $k_{\mathrm{SB}}(91$ days $) /$ rank $\boldsymbol{~ 口 ~} k_{\mathrm{SB}, \mathrm{C}}(91$ days $) /$ rank
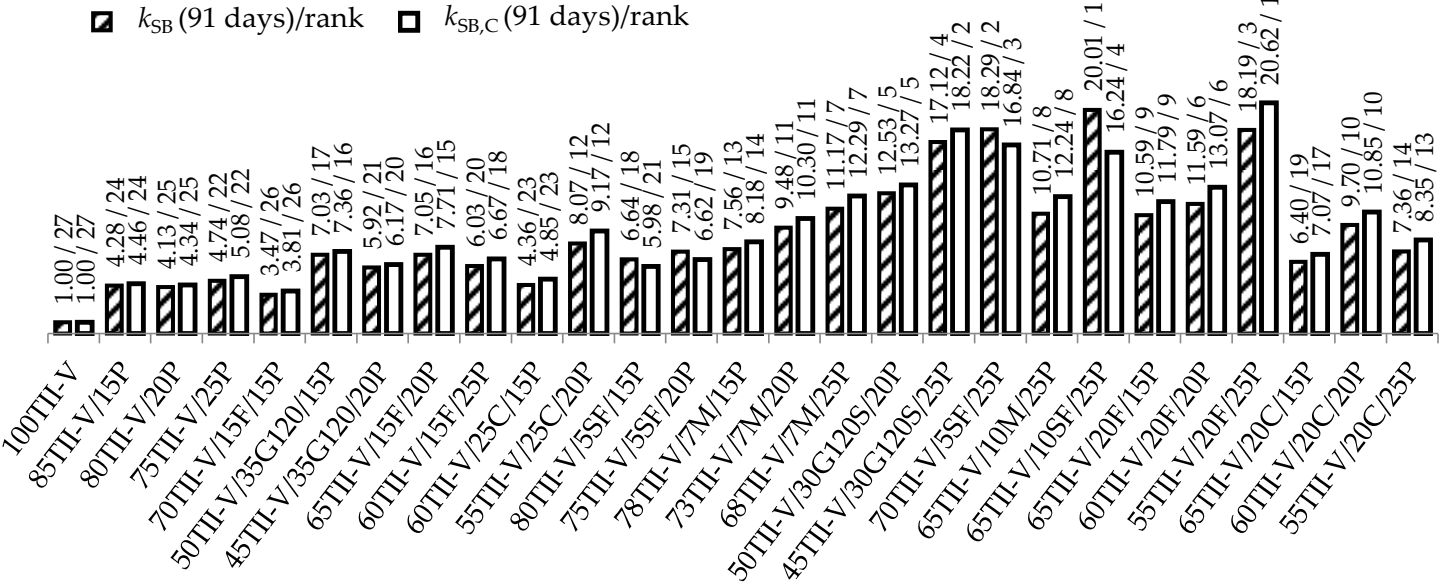

Figure 4. Sustainability indicators and rank of concrete mixtures 91 days after concreting (indicator value/rank).

The reference concrete mixture (100TII-V) has a value of 1 and is ranked $27 \mathrm{th}$, as both indicators for all mixtures showed better performance compared to the reference concrete mixture. The results showed that the best possible mixture in terms of sustainability without cost is $65 \mathrm{TII}-\mathrm{V} / 10 \mathrm{SF} / 25 \mathrm{P}$, whereas, considering the cost, it is $55 \mathrm{TII}-\mathrm{V} / 20 \mathrm{~F} / 25 \mathrm{P}$. This applied to all investigated times. The subsequent rank was different; however, the difference was not significant.

\subsection{Correlation between Sustainability Indicators}

The difference between $k_{\mathrm{SB}}$ was verified by $k_{\mathrm{SB}, \mathrm{C}}$, evaluating the correlation at each time frame (see Figure 5). It could be concluded that both parameters showed similar results based on the high coefficient of the determination values.

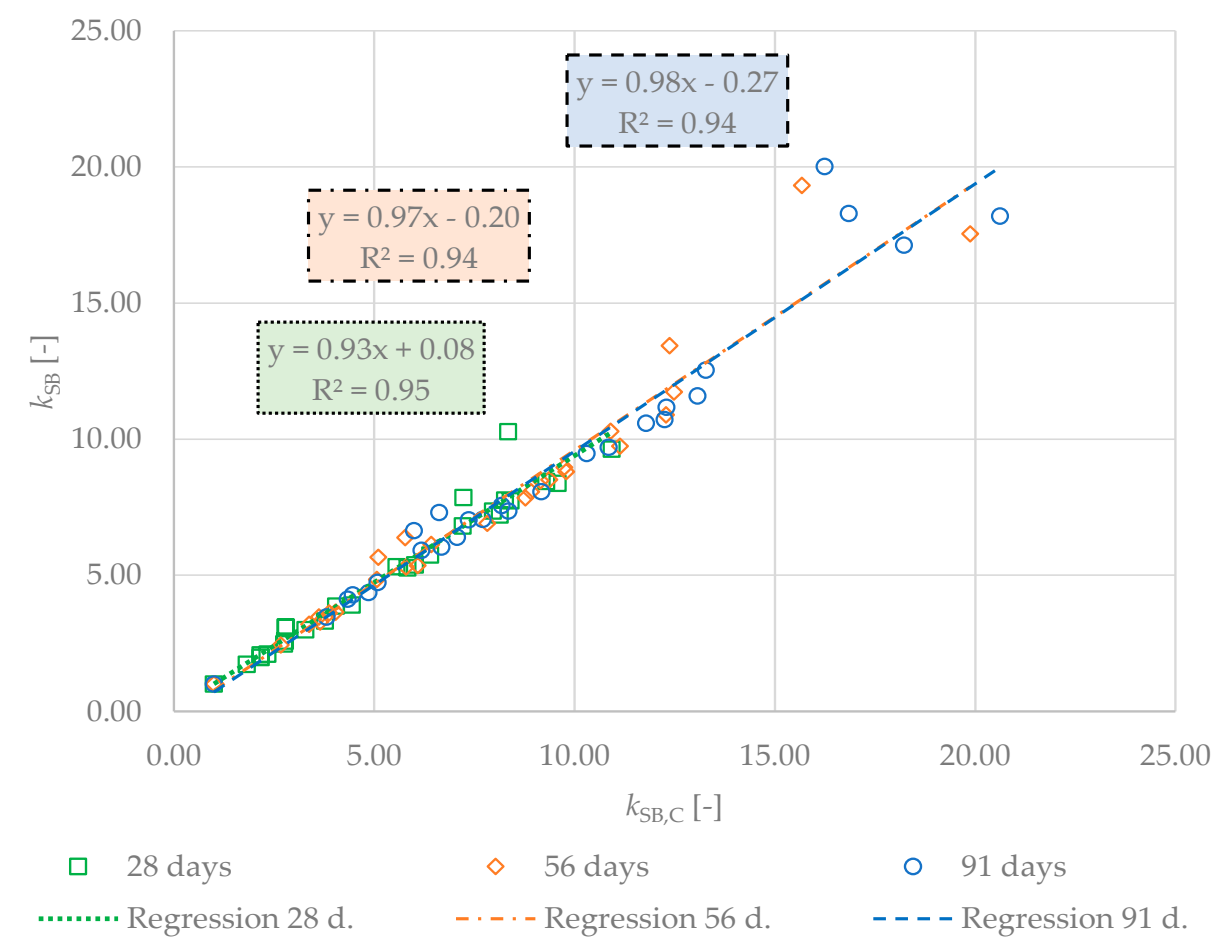

Figure 5. Correlation of $k_{\mathrm{SB}}$ and $k_{\mathrm{SB}, \mathrm{C}}$ for all concrete mixtures.

The major reason was the cost of individual materials, which did not differ significantly from the average value. However, when evaluating an individual mixture, it was observed that the rank was alternate. The highest and lowest correlation was observed in 28 days 
and 91 days, respectively; however, the difference was quite small. Therefore, the relative weight of cost has the same significance as that of other parameters in the case of the studied group of concrete mixtures. As a complementary result, there was a correlation between $k_{\mathrm{SB}}$ values at different times (Figure 6). The values at 28 and 91 days showed the lowest agreement. On the contrary, the highest agreement was observed at 56 and 91 days (which was to be expected, due to the more matured concrete with Pumice SCM).

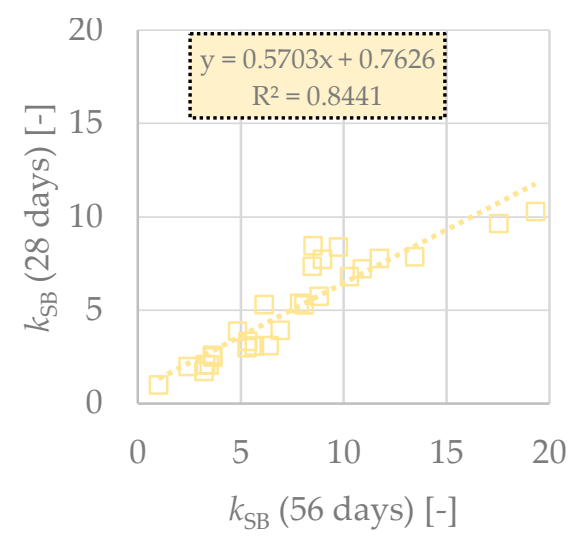

(a)

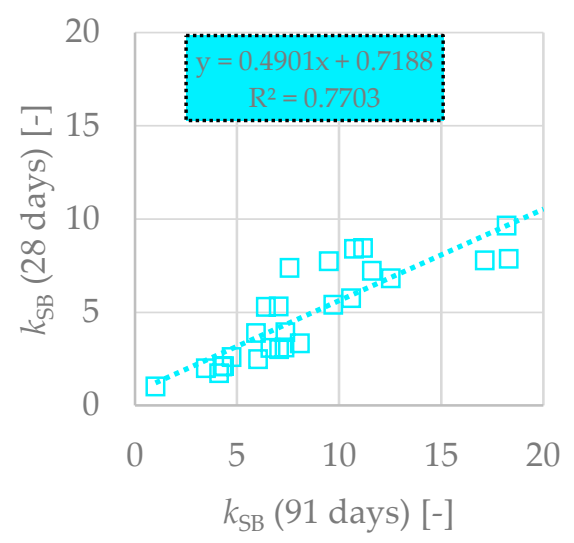

(b)

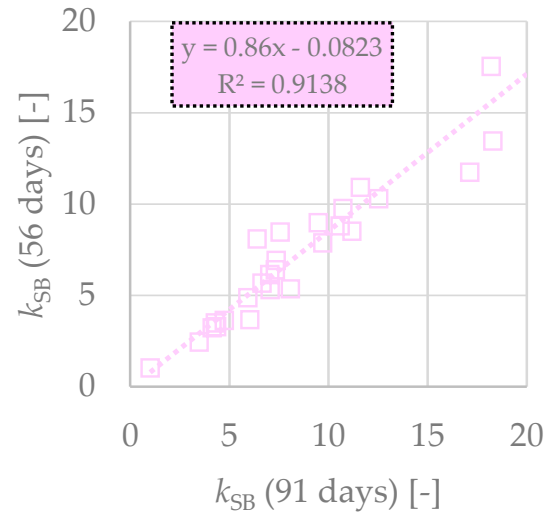

(c)

Figure 6. Correlation of $k_{\mathrm{SB}}$ at different times: (a) 28 days vs. 56 days, (b) 28 days vs. 91 days, (c) 56 days vs. 91 days.

\subsection{Correlation between Sustainability Indicators and Strength}

Correlations were determined to evaluate the hypothesis that the sustainability indicator may suggest a significantly different order of the investigated concrete mixtures compared to the strength (see Figures 7 and 8).

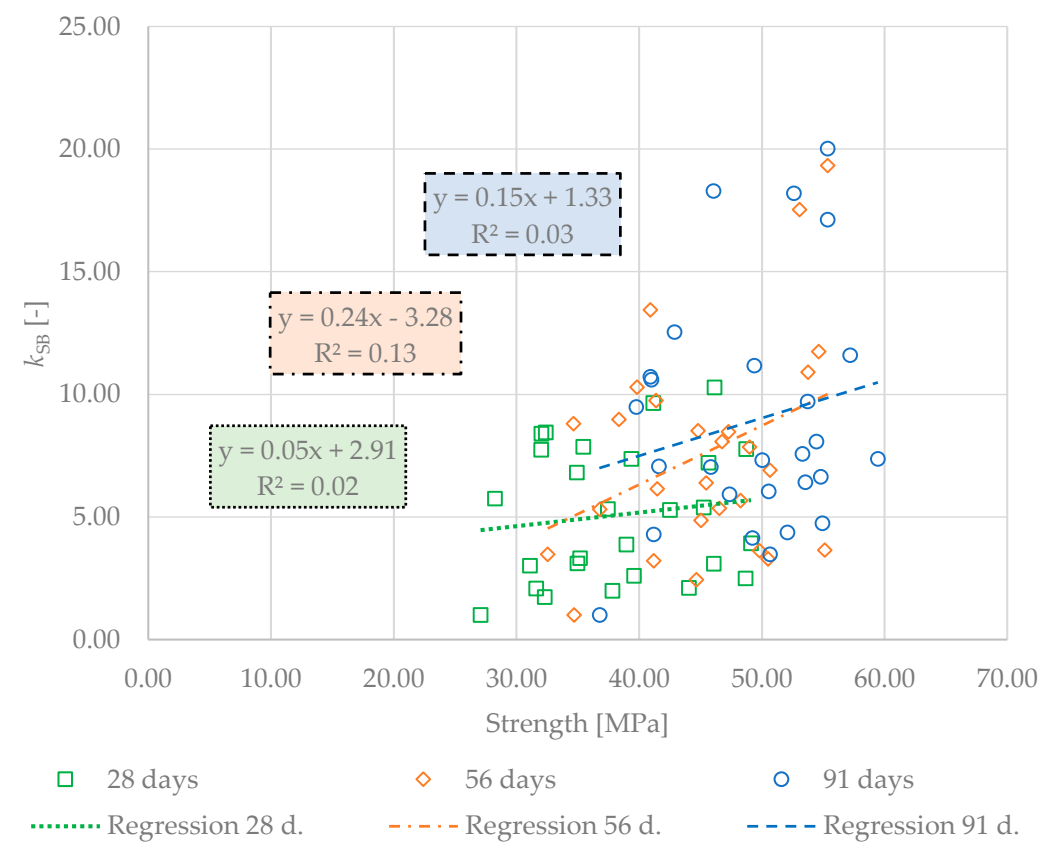

Figure 7. Correlation of $k_{\mathrm{SB}}$ and compressive strength for all concrete mixtures.

It can be observed from the results of the R-square parameters that there was a very low correlation. This proves that both sustainability indicators did not have a direct linear dependence on the strength of the concrete mixtures. This confirmed the first 
assumption that it is appropriate to use these indicators to determine the ranking with respect to sustainability.

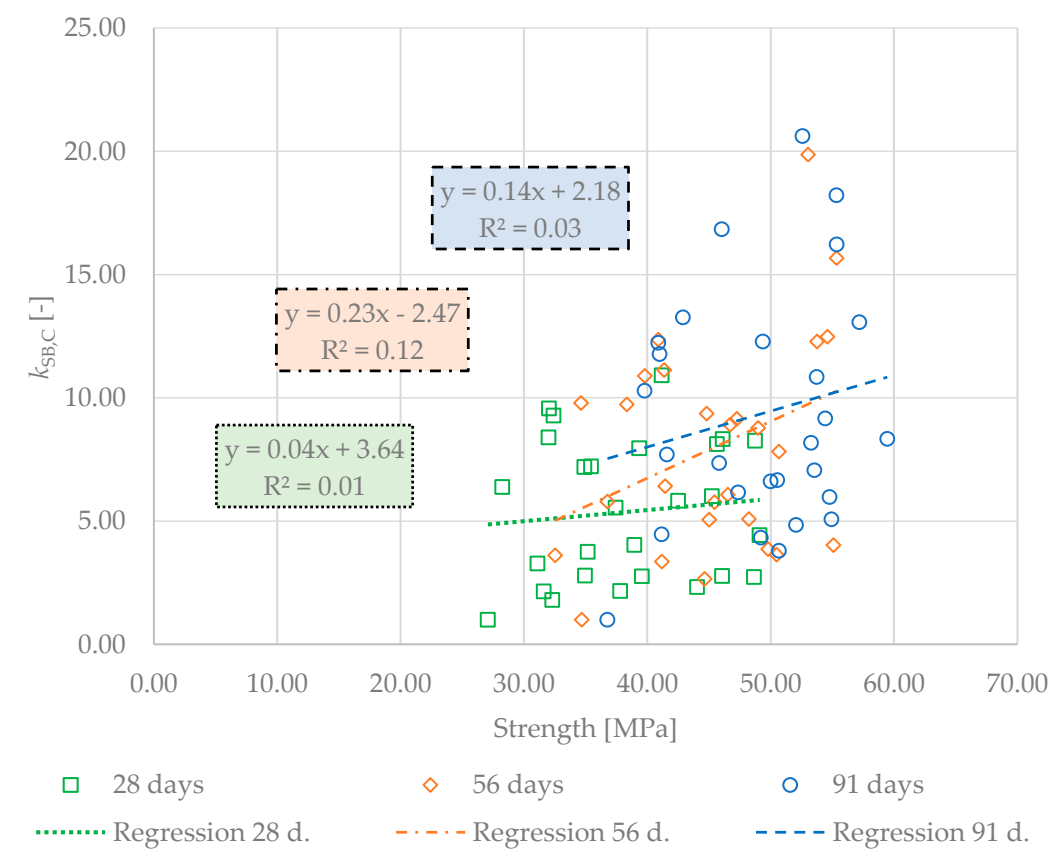

Figure 8. Correlation of $k_{\mathrm{SB}, \mathrm{C}}$ and compressive strength for all concrete mixtures at all studied times.

\subsection{Correlation between Sustainability Indicators and Diffusion Coefficient}

Similarly, correlations were examined to evaluate the hypothesis that the sustainability indicators may suggest a significantly different order of the investigated concrete mixtures compared to the diffusion parameter. This diffusion parameter was used to calculate the resistance of concrete to chloride ions in connection with corrosion of reinforcement (see Figures 9 and 10).

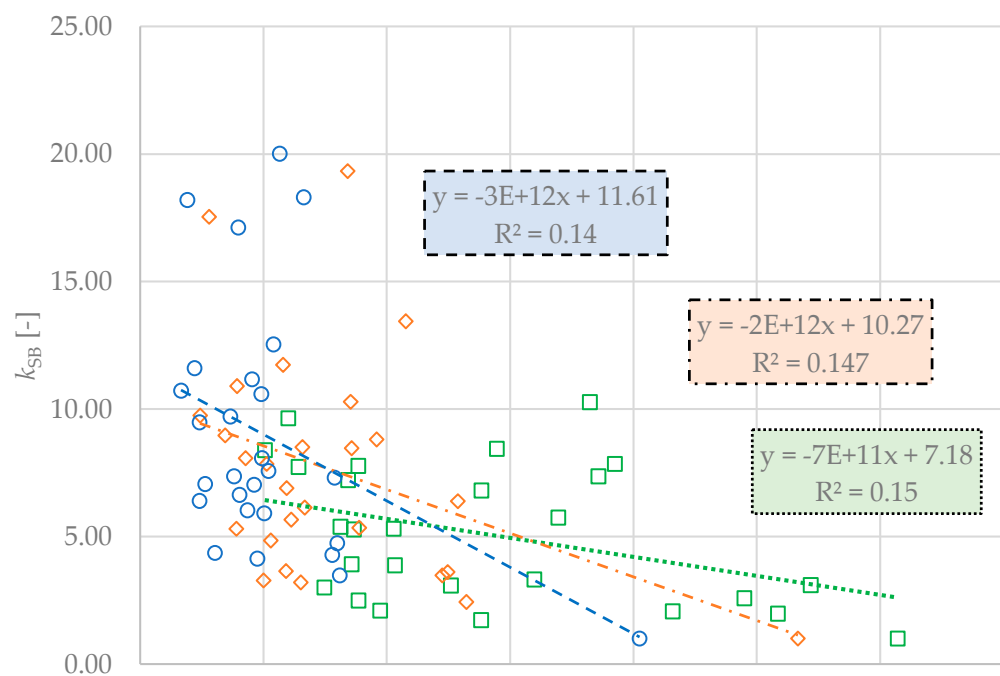

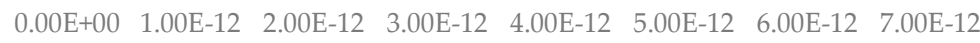
Diffusion coefficient $\left[\mathrm{m}^{2} / \mathrm{s}\right]$
․ 28 days
$\diamond 56$ days
○ 91 days
Regression $28 \mathrm{~d}$.
-.-.- Regression $56 \mathrm{~d}$.
- - - - Regression $91 \mathrm{~d}$.

Figure 9. Correlation of $k_{\mathrm{SB}}$ and the diffusion coefficient for all concrete mixtures. 


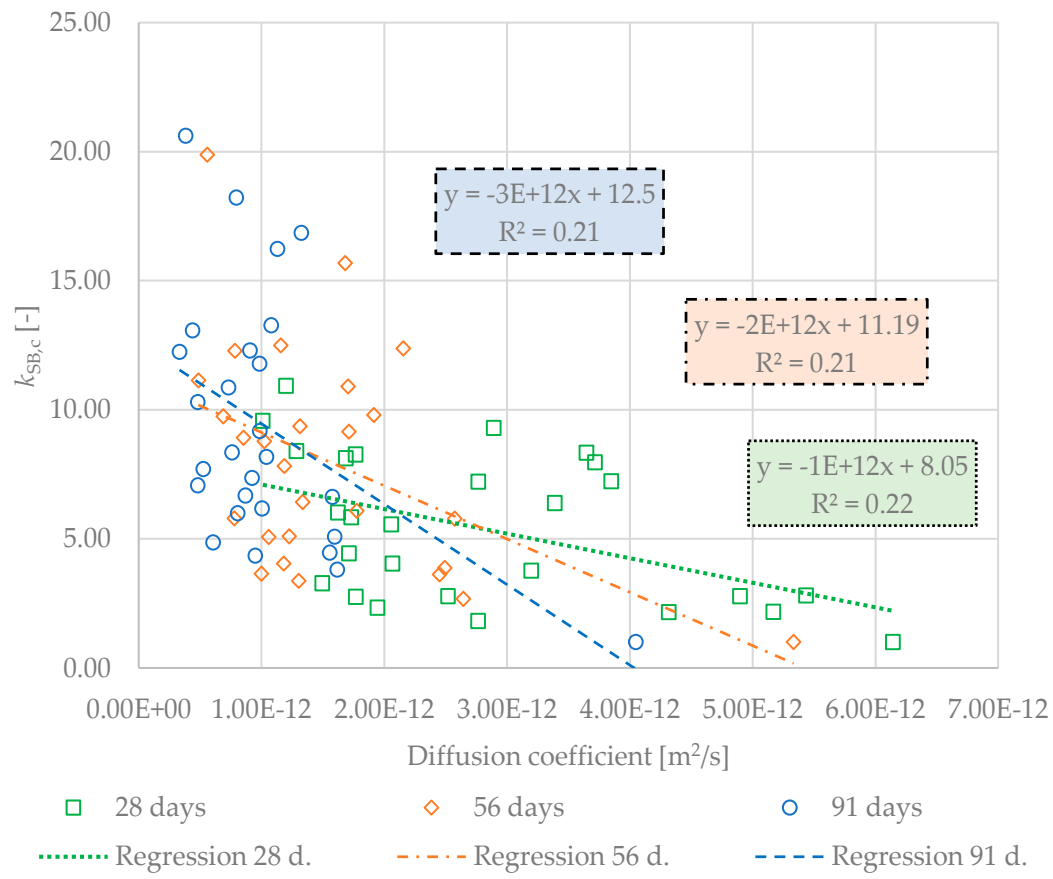

Figure 10. Correlation of $k_{\mathrm{SB}, \mathrm{C}}$ and the diffusion coefficient for all concrete mixtures.

Although the correlation parameter was higher in the results than in the comparison with the strength, it is evident that there was no linear relationship between the diffusion coefficient and the sustainability indicators.

\subsection{Correlation between Sustainability Indicator and Costs}

Finally, the relationship between cost and the sustainability indicator $k_{\mathrm{SB}, \mathrm{C}}$ was studied. There was a need to prove that the cost is not the factor that will affect the most this second indicator. It can be observed from Figure 11 that the correlation coefficient was very low, and the variance of the data showed that there was no direct linear relationship.

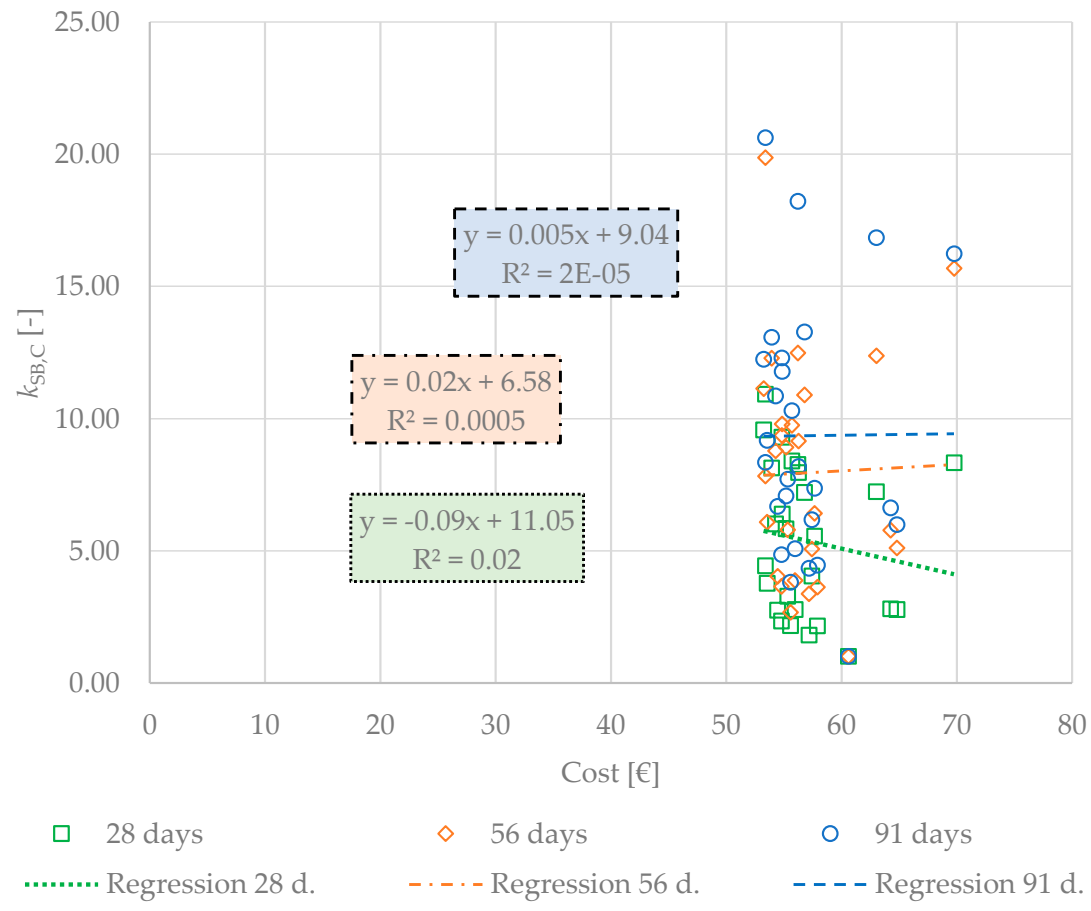

Figure 11. Correlation between $k_{\mathrm{SB}, \mathrm{C}}$ and cost for all concrete mixtures. 


\section{Discussion}

The presented results of rank of 27 pumice-based HPC mixtures can be compared with those of other concrete mixtures. In a previous study [36], an analysis based on the same procedure was presented, with the reference concrete having the same composition and being prepared in the same laboratory investigation. It should be noted that this was a new reference concrete mixture, but the differences in performance, durability, cost, and eco-cost were negligible. Therefore, it is possible to compare the results of both studies. In this previous study [36], other concrete mixtures with different SCMs were also analyzed, and the maximum values of $k_{\mathrm{SB}}$ and $k_{\mathrm{SB}, \mathrm{C}}$ were 4.01 and 3.72 at 91 days. In contrast, significantly higher values were observed for the pumice (VPP) mixtures in this study (maximum 20.01 and 20.62). The strength of the concretes (91 days) in the previous study [36] ranged from $36 \mathrm{MPa}$ to $55 \mathrm{MPa}$, and the pumice mixtures studied here had a strength from $40 \mathrm{MPa}$ to $59 \mathrm{MPa}$ (91 days).

Even though the performance of the pumice mixtures was similar, the ecological aspects are dominant; therefore, the sustainability indicator for volcanic mixtures was significantly higher. Moreover, the remarkable performance in relation to ecological aspects, a reasonable price, and a good performance of Pumice-based mixtures compared to other SCMs previously studied [36] indicate the possibilities to use the $k_{\mathrm{SB}}$ and $k_{\mathrm{SB}, \mathrm{C}}$ sustainability indexes to quantify the level of sustainability, which is essential if sustainability is to be dealt with in engineering operations.

\section{Conclusions}

The methodology for evaluating the sustainability of concrete described and applied in this study provided a rank for the studied group of concretes. The effects of durability, material mechanical properties, and ecological and economic aspects were included. The analysis brought the following major conclusions:

1. The sustainability assessment of volcanic pumice concrete mixture indicated that VPP is a suitable SCM for civil engineering infrastructures, considering eco-friendly aspects. The mixture containing $65 \%$ of Portland Cement Type II-V, $10 \%$ of Silica fume, and $25 \%$ of Volcanic Pumice Pozzolan showed the best values in terms of sustainability, without considering cost.

2. The highest value, considering cost, was assigned to the mixture containing $55 \%$ of Portland Cement Type II-V, 20\% of Class F fly Ash, and 25\% of Volcanic Pumice Pozzolan.

3. The pumice mixtures significantly over performed other SCM-based mixtures on the basis of the evaluated sustainability indicator.

4. The rank of the mixtures was different at different concrete maturity, but the trend was very similar.

5. There was no correlation of strength and the diffusion parameter with sustainability indicators.

6. The present study shows that the $k_{\mathrm{SB}}$ and $k_{\mathrm{SB}, \mathrm{C}}$ sustainability indexes are suitable for quantifying the level of sustainability. Therefore, this study might help the industry to tackle sustainability issues in civil engineering in a rather simple way.

It should be added that the advantage of this procedure is the possibility to consider the various degradation effects, or their combinations, of concrete mixtures containing different SCMs, either with the use of mathematical modelling of service life or with the help of experimental measurements on specific samples. This is an evaluation of the material, which can be used especially at the beginning of the process of designing a concrete structure, when, among other variables, the type of concrete is chosen. At the same time, the sustainability indicator can be viewed as an evaluation tool that can help to choose materials with regard to the issue of carbon footprint. 
Author Contributions: Conceptualization, P.L. and P.K.; methodology, B.T. and P.G.; validation, K.H., P.L. and P.K.; formal analysis, K.H.; investigation, P.G.; resources, K.H.; data curation, B.T.; writingoriginal draft preparation, P.L.; writing—review and editing, P.K., K.H., B.T., and P.G.; visualization, P.L.; supervision, B.T.; project administration, P.K.; funding acquisition, K.H. All authors have read and agreed to the published version of the manuscript.

Funding: Financial support from VŠB-Technical University of Ostrava by means of the Czech Ministry of Education, Youth, and Sports through the Institutional support for the conceptual development of science, research, and innovation for the year 2021 is gratefully acknowledged.

Acknowledgments: Financial support from VŠB-Technical University of Ostrava by means of the Czech Ministry of Education, Youth, and Sports through the Institutional support for the conceptual development of science, research, and innovation for the year 2021 is gratefully acknowledged.

Conflicts of Interest: The authors declare no conflict of interest.

\section{References}

1. Angst, U.M. Challenges and opportunities in corrosion of steel in concrete. Mater. Struct. 2018, 51, 4. [CrossRef]

2. Durastanti, C.; Moretti, L. Environmental Impacts of Cement Production: A Statistical Analysis. Appl. Sci. 2020, 10, 8212. [CrossRef]

3. Katzer, J.; Domski, J. Quality and mechanical properties of engineered steel fibres used as reinforcement for concrete. Constr. Build. Mater. 2012, 34, 243-248. [CrossRef]

4. Horńáková, M.; Lehner, P. Relationship of surface and bulk resistivity in the case of mechanically damaged fibre reinforced red ceramic waste aggregate concrete. Materials 2020, 13, 5501. [CrossRef]

5. Lloyd, N.A.; Rangan, B.V. Geopolymer concrete: A review of development and opportunities. In Proceedings of the 35th Conference on Our World in Concrete and Structures, Singapore Concrete Institute, Singapore, 25-27 August 2010; pp. 25-27.

6. Silva, R.V.; De Brito, J.; Dhir, R.K. Properties and composition of recycled aggregates from construction and demolition waste suitable for concrete production. Constr. Build. Mater. 2014, 65, 201-217. [CrossRef]

7. Purnell, P. Material nature versus structural nurture: The embodied carbon of fundamental structural elements. Environ. Sci. Technol. 2012, 46, 454-461. [CrossRef]

8. Damineli, B.L.; Kemeid, F.M.; Aguiar, P.S.; John, V.M. Measuring the eco-efficiency of cement use. Cem. Concr. Compos. 2010, 32, 555-562. [CrossRef]

9. Barker, D.J.; Turner, S.A.; Napier-Moore, P.A.; Clark, M.; Davison, J.E. $\mathrm{CO}_{2}$ Capture in the Cement Industry. Energy Procedia 2009, 1, 87-94. [CrossRef]

10. Benhelal, E.; Zahedi, G.; Shamsaei, E.; Bahadori, A. Global strategies and potentials to curb $\mathrm{CO}_{2}$ emissions in cement industry. J. Clean. Prod. 2013, 51, 142-161. [CrossRef]

11. Lippiatt, N.; Ling, T.-C.; Pan, S.-Y. Towards carbon-neutral construction materials: Carbonation of cement-based materials and the future perspective. J. Build. Eng. 2020, 28, 101062. [CrossRef]

12. de Brito, J.; Kurda, R. The past and future of sustainable concrete: A critical review and new strategies on cement-based materials. J. Clean. Prod. 2021, 281, 123558. [CrossRef]

13. Zhao, H.; Sun, W.; Wu, X.; Gao, B. The properties of the self-compacting concrete with fly ash and ground granulated blast furnace slag mineral admixtures. J. Clean. Prod. 2015, 95, 66-74. [CrossRef]

14. Zhang, Z.; Provis, J.L.; Zou, J.; Reid, A.; Wang, H. Toward an indexing approach to evaluate fly ashes for geopolymer manufacture. Cem. Concr. Res. 2016, 85, 163-173. [CrossRef]

15. Younsi, A.; Turcry, P.; Rozière, E.; Aït-Mokhtar, A.; Loukili, A. Performance-based design and carbonation of concrete with high fly ash content. Cem. Concr. Compos. 2011, 33, 993-1000. [CrossRef]

16. Sujjavanich, S.; Suwanvitaya, P.; Chaysuwan, D.; Heness, G. Synergistic effect of metakaolin and fly ash on properties of concrete. Constr. Build. Mater. 2017, 155, 830-837. [CrossRef]

17. Ghosh, P.; Tran, Q. Correlation Between Bulk and Surface Resistivity of Concrete. Int. J. Concr. Struct. Mater. 2015, 9, 119-132. [CrossRef]

18. Lehner, P.; Konečný, P.; Ponikiewski, T. Comparison of material properties of scc concrete with steel fibres related to ingress of chlorides. Crystals 2020, 10, 220. [CrossRef]

19. Millar, S.; Wilsch, G.; Eichler, T.; Gottlieb, C.; Wiggenhauser, H. Laser Induced Breakdown Spectroscopy (LIBS) in civil engineering-Innovative analysis of building materials [Laser Induced Breakdown Spectroscopy (LIBS) im BauwesenAutomatisierte Baustoffanalyse]. Beton-und Stahlbetonbau 2015, 110, 501-510. [CrossRef]

20. Nguyen, P.T.; Bastidas-Arteaga, E.; Amiri, O.; El Soueidy, C.P. An Efficient Chloride Ingress Model for Long-Term Lifetime Assessment of Reinforced Concrete Structures Under Realistic Climate and Exposure Conditions. Int. J. Concr. Struct. Mater. 2017, 11, 199-213. [CrossRef]

21. Hossain, K.M.A.; Lachemi, M. Performance of volcanic ash and pumice based blended cement concrete in mixed sulfate environment. Cem. Concr. Res. 2006, 36, 1123-1133. [CrossRef] 
22. Anwar Hossain, K.M. Properties of volcanic pumice based cement and lightweight concrete. Cem. Concr. Res. 2004, 34, $283-291$. [CrossRef]

23. Ulusu, H.; Aruntas, H.Y.; Gencel, O. Investigation on characteristics of blended cements containing pumice. Constr. Build. Mater. 2016, 118, 11-19. [CrossRef]

24. Nozahic, V.; Amziane, S.; Torrent, G.; Saïdi, K.; De Baynast, H. Design of green concrete made of plant-derived aggregates and a pumice-lime binder. Cem. Concr. Compos. 2012, 34, 231-241. [CrossRef]

25. Yadollahi, M.M.; Benli, A.; Demirboğa, R. The effects of silica modulus and aging on compressive strength of pumice-based geopolymer composites. Constr. Build. Mater. 2015, 94, 767-774. [CrossRef]

26. Tran, Q.; Ghosh, P. Influence of pumice on mechanical properties and durability of high performance concrete. Constr. Build. Mater. 2020, 249, 118741. [CrossRef]

27. Biondini, F.; Frangopol, D.M. Probabilistic limit analysis and lifetime prediction of concrete structures. Struct. Infrastruct. Eng. 2008, 4, 399-412. [CrossRef]

28. Teplý, B.; Podroužek, J. Service life, reliability and their role in the life cycle analysis of concrete structures. Adv. Environ. Res. 2017, 55, 47-63.

29. Kumar, R.; Gardoni, P.; Sanchez-Silva, M. Effect of cumulative seismic damage and corrosion on the life-cycle cost of reinforced concrete bridges. Earthq. Eng. Struct. Dyn. 2009. [CrossRef]

30. Martín-Pérez, B.; Zibara, H.; Hooton, R.; Thomas, M.D. A study of the effect of chloride binding on service life predictions. Cem. Concr. Res. 2000, 30, 1215-1223. [CrossRef]

31. Matthews, S. fib Model Code 2020-A new development in structural codes. Struct. Concr. 2017, 651-652. [CrossRef]

32. Kloepffer, W. Life cycle sustainability assessment of products. Int. J. Life Cycle Assess. 2008, 13, 89-95. [CrossRef]

33. Hrabova, K.; Teply, B.; Vymazal, T. Sustainability assessment of concrete mixes. IOP Conf. Ser. Earth Environ. Sci. 2020, 444, 012021. [CrossRef]

34. Teplý, B.; Rovnaníková, P.; Vymazal, T. Sustainability Quantification of Concrete Structures. In Advances in Environmental Research; NOVA Science Publishers: New York, NY, USA, 2018; ISBN 978-1-53613-918-1.

35. Müller, H.S. Sustainable structural concrete-From today's approach to future challenge. Struct. Concr. 2013, 14, 299-300. [CrossRef]

36. Konečný, P.; Ghosh, P.; Hrabová, K.; Lehner, P.; Teplý, B. Effective methodology of sustainability assessment of concrete mixtures. Mater. Struct. Constr. 2020, 53. [CrossRef]

37. Opon, J.; Henry, M. An indicator framework for quantifying the sustainability of concrete materials from the perspectives of global sustainable development. J. Clean. Prod. 2019, 218, 718-737. [CrossRef]

38. ACI Committee 318. Building Code Requirements for Structural Concrete: (ACI 318-95); and Commentary (ACI 318R-95); American Concrete Institute: Farmington Hills, MI, USA, 1995.

39. Matthews, S. Fib Model Code 2020. Struct. Concr. 2019, 20, 860-866. [CrossRef]

40. De Schepper, M.; Van den Heede, P.; Van Driessche, I.; De Belie, N. Life Cycle Assessment of Completely Recyclable Concrete. Materials 2014, 7, 6010-6027. [CrossRef]

41. Chappex, T.; Scrivener, K. Alkali fixation of C-S-H in blended cement pastes and its relation to alkali silica reaction. Cem. Concr. Res. 2012. [CrossRef]

42. ASTM C1202 Standard Test Method for Electrical Indication of Concrete's Ability to Resist Chloride Ion Penetration. Am. Soc. Test. Mater. 2012, 1-8. [CrossRef]

43. Paredes, M.; Jackson, N.M.; El Safty, A.; Dryden, J.; Joson, J.; Lerma, H.; Hersey, J. Precision Statements for the Surface Resistivity of Water Cured Concrete Cylinders in the Laboratory. Adv. Civ. Eng. Mater. 2012, 1, 1-23. [CrossRef]

44. Lu, X. Application of the Nernst-Einstein equation to concrete. Cem. Concr. Res. 1997, 27, 293-302. [CrossRef]

45. Eco Costs Data Design-4-Sustainability: Inspiration and Knowledge by Designers for Designers. Available online: http://www. design-4-sustainability.com/ecocosts (accessed on 1 January 2021).

46. The Model of the Eco-Costs/Value Ratio (EVR). Available online: http://www.ecocostsvalue.com/ (accessed on 1 January 2021).

47. Vymazal, T.; Teply, B.; Hrabova, K. The assessment and prediction of concrete sustainability. IOP Conf. Ser. Mater. Sci. Eng. 2019, 583, 012035. [CrossRef] 